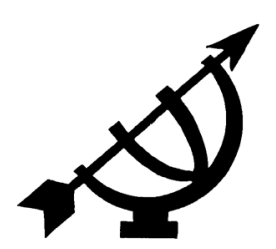

\title{
The relationship between locus of control and ethical behaviour among employees in the financial sector
}

\author{
E. Boshoff \& E.S. van Zyl \\ Faculty of Economic \& Management Sciences \\ Department of Industrial Psychology \\ University of the Free State \\ BLOEMFONTEIN \\ E-mail: boshoffe@ufs.ac.za \\ vanzyles@ufs.ac.za
}

\begin{abstract}
The relationship between locus of control and ethical behaviour among employees in the financial sector
\end{abstract}

Unethical behaviour is a rapidly escalating trend in the current work situation, where - within organisations - there appears to be a decrease in ethical behaviour at a national as well as international level. Employees within the financial sector form a specific area of interest concerning ethical behaviour in South Africa. Various incidents of unethical conduct are reported within the financial sector, necessitating a specific focus on factors which may influence ethical behaviour. Current research supports a person-situation-interaction approach to ethical decision-making, where both individual and situational factors influence the decisions of individuals. Research indicate that individual factors such as locus of control may influence ethical behaviour. The way these variables are related among employees in the financial sector in South Africa, however, has not as yet been demonstrated. In order to determine the relationship between locus of control and ethical behaviour, Schepers' Locus of Control Questionnaire and the Work Beliefs Questionnaire were administered to 100 employees in the financial sector in Bloemfontein. Statistically significant relationships $(p \leq 0,05)$ were found between internal locus of control and ethical behaviour, external locus of control and ethical behaviour, as well as autonomy and ethical behaviour. Recommendations were made in the light of the results regarding the development 
of strategies and interventions to minimise unethical behaviour within organisations.

\section{Opsomming}

\section{Die verband tussen lokus van beheer en etiese gedrag onder werknemers in die finansiële sektor}

Onetiese gedrag is 'n snel-eskalerende tendens in die huidige werksituasie, waar daar binne organisasies 'n verval in etiese gedrag op nasionale sowel as internasionale vlak blyk te wees. Werknemers in die finansiële sektor in Suid-Afrika vorm 'n bepaalde area van belang rakende etiese gedrag. Verskeie insidente van onetiese gedrag word binne die finansiële sektor gerapporteer en noodsaak 'n fokus op faktore wat etiese gedrag mag beïnvloed. Huidige navorsing ondersteun 'n persoonsituasie-interaksiebenadering tot etiese bes/uitneming, waar sowel individuele as situasionele faktore die individu se besluite beïnvloed. Navorsing dui daarop dat individuele faktore soos lokus van beheer 'n invloed op etiese gedrag mag uitoefen. Die wyse waarvolgens hierdie veranderlikes met mekaar verband hou, is nog nie ondersoek ten opsigte van werknemers in die Suid-Afrikaanse finansiële sektor nie. Ten einde die verband tussen lokus van beheer en etiese gedrag te bepaal, is Schepers se Lokus van Beheervraelys asook die Werksoortuigingsvraelys afgeneem op 100 werknemers in die finansiële sektor in Bloemfontein. Statisties-beduidende verbande $(p \leq 0,05)$ is gevind tussen interne lokus van beheer en etiese gedrag, eksterne lokus van beheer en etiese gedrag, asook outonomie en etiese gedrag. Op grond van die resultate is aanbevelings gemaak aangaande die ontwikkeling van strategieë en intervensies om onetiese gedrag binne organisasies te verminder.

\section{Introduction}

Business ethics is neither a new nor unfamiliar phenomenon. Indeed, philosophy regarding the relationship between business and morality has been underway since ancient times (Freeman, 1991:3). According to Malan and Smit (2001:1) a shared vision of political stability, economic progress and personal safety for all in South Africa was established following the democratic election in 1994.

After the election in 1994, however, the opposite realised. Murder, high-jacking, rape and corruption are reported daily in the media. As early as 1999 Thabo Mbeki (then vice-president) declared the battle against crime a national priority (Gloek \& De Jager, 2005:49). Mbeki once again confirmed this belief in 2005 by stating the following as president of the country: 
Fraud and corruption ... is inimical to development. It constrains our ability to fight poverty, negatively affects economic development, damages social values and undermines democracy and good governance. (Gloek \& De Jager, 2005:49.)

According to Squire (2007:par.1) there is a national as well as an international drop in the level of ethical behaviour within organisations. In this regard fraud appears to be a worldwide concern within organisations. For the period 2005 to 2007, crime has occurred in one out of every two organisations on an international level (PricewaterhouseCoopers, 2007:2). Rabl and Kühlmann (2008:477) confirm that corruption is a serious problem worldwide, not only in the political arena, but also within the business sector. South Africa is no exception in this regard, and De Koker (2007:37) states that crime has reached unacceptable levels in South Africa. Despite the attention devoted to crime, the levels of economic crime - and the financial and non-financial consequences thereof - have increased (PricewaterhouseCoopers, 2007:2). South Africa is also regarded as the country with the highest white-collar crime worldwide. South African organisations had an average of 23 cases of fraud per year reported for the time period between 2006 and 2007, with an average loss of income of R7,4 million for that period (Anon., 2007:1).

According to De Koker $(2007: 35,37)$ unethical behaviour is of specific concern within the financial sector. The problematic situation regarding business ethics - particularly in the financial sector - is emphasised in current literature, as there have been various ethical scandals in prominent companies in the past ten years (Du Toit et al., 2007:16). According to Safakli (2005:24) the most common unethical behaviour in the financial sector, with specific reference to the banking sector, include misuse of authority, bribery and exploitation. Other ethical issues concerning the banking industry include political inferences such as the use of influence to finance risky public investments. According to Falconer (2005:103) the previously unquestioned ethical reputation of the financial sector is increasingly being questioned by both consumers and the media, in terms of the sector's honesty, integrity and reliability. The importance of ethical practices, and the consequences of unethical decision-making within the financial industry, must, therefore, receive increased attention.

In the light of the aforementioned, it is important to focus on factors which may have an influence on ethical behaviour. According to Stead et al. (1994:59), Chonko et al. (1996:44) as well as Hume et al. (2006:56) individual factors such as locus of control may influence employees' decisions to behave ethically or unethically at 
work. The way locus of control may influence ethical behaviour among employees working in the South African financial sector, however, has not yet been demonstrated.

Based on the abovementioned, the assumption can be made that locus of control can be linked to ethical behaviour. This relation confirms the necessity for research into this area of influence upon ethical behaviour, in order to increase knowledge and understanding of both phenomena (ethical behaviour and locus of control) and to make practical recommendations towards aiding the increase of ethical behaviour among employees within the financial sector in South Africa.

\section{Ethical behaviour}

\subsection{Concept definition}

The word ethics is derived from the Greek word ethos, which means character (Duska, 2005:27). According to Safakli (2005:24) ethics refers to the standards of right and wrong that prescribe what humans ought to do. Grobler et al. (2006:32) add to this by describing ethics as a discipline which deals with obligations and moral duty, or with what is good and bad, right and wrong.

Towards an understanding of business ethics, Trevino and Nelson (2007:16) define business ethics as the study of behaviour within a business context which is consistent with the principles, norms and standards of business practices as agreed with the community. Furthermore, Weiss (1998:7) states that there is no clear definition for the term business ethics, but confirms the consensus that business ethics require reasoning and judgement based on beliefs and principles for making choices, which balance economic self interests against welfare and social claims. Nash (1994:11) adds to this by stating that business ethics is a study of how personal moral norms relate to the goals and activities of commercial enterprise. Ethics is therefore not a separate moral standard, but a study of how the business environment presents its own unique problems for a moral person functioning within the business context.

\subsection{The development of an ethical disposition}

From the aforementioned discussion regarding the nature and definition of the construct ethics, and specifically business ethics, the question arises regarding the means by which an ethical disposition 
develops. In the following, the focus will be placed on two prominent approaches regarding moral development.

\subsubsection{The cognitive-structural approach}

Kohlberg's moral reasoning theory is central to the cognitive-structural field of moral reasoning. According to Kohlberg's theory (Kohlberg, 1969:376; Gerdes et al., 1988:291-293; Parsons, 2007:54-56; Trevino \& Nelson, 2007:126-128), moral reasoning develops sequentially through three broad levels, each composed of two stages.

The pre-conventional level of moral development is particularly characteristic of the mid-childhood years (age five to nine years). Two stages within this level are distinguished, namely the "punishmentobedience orientation" (stage 1), and the "naive hedonistic and instrumental orientation" (stage 2). During stage 1 behaviour is only evaluated according to the consequences thereof. Decisions rest solely on the avoidance of punishment irrespective of others' needs. During stage 2 the individual's behaviour is directed towards personal advantage and interest. There is an expectation that, should something be done for someone else, the said person will return the action.

The conventional level of moral development is characteristic of most adolescents and adults. The two stages distinguished on this level are "the good son/daughter orientation" (stage 3), and the "law and order orientation" (stage 4). During stage 3 behaviour deemed morally right is viewed as that behaviour which benefits or helps others, as well as behaviour which is approved of by close others. Therefore, an attempt is made to avoid critique and receive approval. During stage 4, moral behaviour is associated with performance, respect for authority, and maintenance of existing social law and order.

The post-conventional level of moral development is characteristic of individuals who define moral values and principles in isolation from the authority of the groups of persons who maintain these principles. Individuals are thus able to make rational decisions between conflicting standards. The following two stages are distinguished within this level, namely the "social contract orientation" (stage 5), and "orientation according to universally ethical principles" (stage 6). During stage 5, right or wrong behaviour is defined in terms of laws and established rules. In addition to laws and rules the individual's personal values and beliefs serve as a yardstick of what is right or wrong. Should conflict exist between the individual's standards and 
certain established rules and laws, the society's rules and laws are accepted, as the individual views it as morally compulsory to abide by society's rules and laws. During the final stage of moral development (stage 6) the individual judges behaviour not only according to existing norms, but personal conscience and self-chosen internalised, abstract ethical principles too.

According to Weiss (1998:21) research indicated that the majority of adults reach the fourth or fifth stage of moral reasoning, and only a small percentage the sixth stage. Kohlberg (1969:376-379; Trevino \& Nelson, 2007:125) states furthermore that the higher the individual's level of reasoning, the more ethical the decision made by them.

\subsubsection{The sociological approach}

From the cognitive approach, the important role played by the social environment in the forming of behaviour, comes clearly to the fore. Neubeck and Glasberg (1996:139) state furthermore that the individual's social identity is formed during socialisation. Individuals learn, accept, reject and change the norms, values, assumptions and expectations of the community which they form part of. The community in turn is often influenced by institutions such as religion. According to O'Donnel and Garrod (1990:11), Neubeck and Glasberg (1996:146-148), and Malan and Smit (2001:75-78) the following role players can be differentiated during the socialisation process: the family, community, school, church, media, work and the peer group which the individual forms part of. The child adopts his first convictions and values from his parents. Children accept these convictions and values as parents require it of them, though they may not yet understand it. Parents learn the values and norms from the culture and religion which they form part of. Culture refers primarily to the shared lifestyle between members of a community. Culture also refers to agreements between members of a community regarding appropriate behaviour, values, norms, rituals and origin.

Malan and Smit (2001:75) indicate that, although parents establish the basis for the child's knowledge, beliefs and assumptions, the child's exposure to other influences within the family (such as electronic media for instance) exert an additional influence on the formation of beliefs and a frame of reference. According to Malan and Smit $(2001: 75,78)$ the quality of children's development within the family influences their future development. Children will interpret information passed on to them by the school or other individuals 
within their frame of reference which they formed in the family. Should information concur with what the child learned in the family, it will be reinforced. However, should the information differ, children may begin to question what they learnt at home, and identify themselves with external definitions of what is right and wrong, as well as external moral guidelines. Therefore, comprehensive teaching by competent teachers is important in the education and development of the child, as is a sound foundation for Christians in Christian principles. From all these influences the child must make a choice between what to accept and reject. Parents and religion have the advantage that the first five years are critical in the child's development. Should the parents be supported by the church and school, these role players can contribute to the internalisation of sustainable values and a high level of morality in the child.

Morals, beliefs and principles stemming primarily from socialisation are thus inexplicably linked to a chief socialisation agent - religion. Religion plays a vital role in the establishment of a system of values in the individual. According to Kennedy and Lawton (1998:163) a negative relationship exists between religiosity and individuals' willingness to become involved in unethical practices. Religion offers norms which decrease conflict within communities and between individuals, and places sanctions on antisocial behaviour. Therefore, religion serves as an important regulator of behaviour, including ethical behaviour. Religion, however, does not merely regulate behaviour in our everyday interaction with one another. It also has a central position in terms of all aspects of the individual's life, including the individual's role as an employee within the organisational context.

\subsection{Theoretical model of ethical behaviour}

A pivotal question arising is which approaches may be followed during ethical decision-making, as well as which factors may exert an influence during ethical decision-making. The following model Stead, Worrel and Stead's theoretical model of ethical behaviour will be elucidated in answer to the aforementioned concerns.

\subsubsection{Stead, Worrel and Stead's theoretical model of ethical behaviour}

According to Stead et al. (1994:58) research supports a personsituation explanation of ethical behaviour, wherein individual and situational (organisational) factors influence the decisions made by individuals. According to Stead et al. (1994:64) the theoretical model 
consists of two phases, which can be presented schematically as follows:

\section{Figure 1: Stead, Worrel \& Stead's theoretical model of ethical} behaviour (Stead et al., 1994:64)

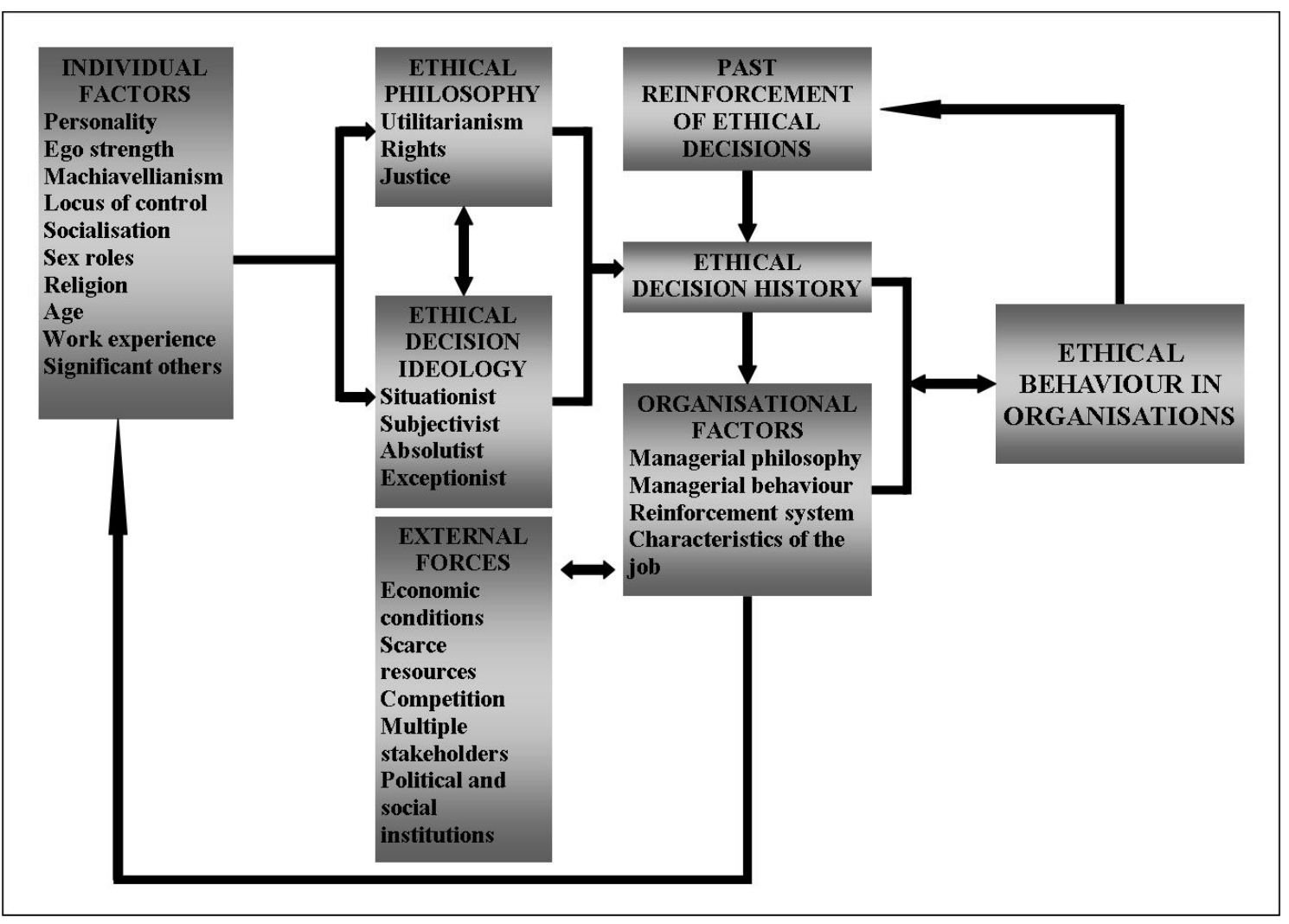

\section{- First phase}

The first phase indicates the relationship between individual factors and the development of the individual's ethical system (that is, the individual's ethical philosophy - as outlined in Boshoff's holisticphilosophical model of ethical decision-making, as well as the individual's ethical behaviour). This phase encompasses the manner in which the individual's ethical beliefs are influenced by personality and socialisation.

According to Stead et al. (1994:59) three personality measures may influence ethical behaviour, namely ego strength, Machiavellianism and locus of control. Hume et al. (2006:56) add that locus of control has a significant influence on ethical behaviour. With regards to socialisation, Stead et al. (1994:59) indicate that factors such as age, work experience, nationality, sex role differences, and religious beliefs may influence ethical behaviour. 


\section{- Second phase}

The individual enters an organisation during the second phase, and is exposed to various organisational factors such as a managerial philosophy, managerial behaviours, reinforcement systems and characteristics of the job, which may have a definite influence on the ethical behaviour of the individual (Stead et al., 1994:61).

Various external forces such as competitive pressures, resource needs, economic conditions, scarce resources, political and social institutions, and multiple stakeholders simultaneously influence the individual's ethical behaviour. Companies frequently have to choose between ethical conduct, at the possible sacrifice of competitive edge, and ethically questionable behaviour for the sake of profitability (Stead et al., 1994:62). Stead et al. (1994:62) state that resource scarcity, volatile economic conditions, and pressure from stakeholders may undermine ethical behaviour in organisations.

\section{Locus of control}

According to Spector (2008:236) and Hellrigel et al. (2010:82) locus of control refers to the extent to which individuals believe that they can control events which affect them. Rotter (1966:1) distinguishes between two orientations in locus of control, namely an internal and external orientation. Rotter defines internal locus of control as the degree to which individuals feel in control of their behaviour. Such individuals would be inclined to hold that God helps those who help themselves (Rotter, 1966:1; Spector, 2008:236). According to Rotter external locus of control can be defined as the degree to which external factors (e.g. luck or fate) control behaviour (Rotter, 1966:1; Spector, 2008:237). Besides internal and external locus of control, Schepers (1995:2) identifies a third dimension of the locus of control construct, namely autonomy. Schepers (2005:2) defines autonomy as "the tendency to attempt to master or be effective in the environment, to impose one's wishes and designs on it".

The locus of control construct was conceived from Rotter's social learning theory and Heider's attribution theory (Bothma \& Schepers, 1997:45). According to the social learning theory, reinforcement of behaviour leads to a heightened expectation that specific behaviour will lead to the same reinforcement in the future. Therefore, the reaction to an occurrence is largely determined by an individual's perception that a reward will follow a specific behaviour. This is in contrast to the degree to which the reward is experienced as being controlled by external powers, regardless of individual behaviour. 
The social learning theory proposes that both reinforcement and punishment have indirect effects on learning, and that reinforcement and punishment influences the extent to which an individual exhibits a behaviour which has been learned (Bothma \& Schepers, 1997:45; Boshoff, 2001:44; Schepers, 2005:2).

The attribution theory forms the theoretical basis for the clarification of the means by which individuals interpret others' behaviour, by providing causal explanations for behaviour (Heider, 1958; Martin, 2005:99; Robbins \& Judge, 2007:56; Boshoff 2009:65). The attribution theory was developed by Fritz Heider, and is based on the principle that behaviour can be attributed to internal factors that are related to the individual (e.g. ability and motivation), or external factors from the environment (e.g. level of difficulty of the task and aid from others) (Heider, 1958; McShane \& Von Glinow, 2000:174; Kreitner \& Kinicki, 2007:224; Boshoff 2009:65). Three criteria which determine whether an individual will develop an internal or external attribution can be identified, namely differentiation (which refers to an individual's unique behaviour in a specific situation), consistency (which refers to the stability of an individual's behaviour and the degree to which an individual displays the same behaviour in similar situations at different times), and consensus (which refers to the degree to which an individual's behaviour concurs with the behaviour of other individuals who find themselves in similar situations) (Greenberg \& Baron, 2000:58; Kreitner \& Kinicki, 2007:224-225; Robbins \& Judge, 2007:148-149; Boshoff 2009:65-66).

Should it be observed that the person's behaviour corresponds with the behaviour of other persons (consensus is high), that the person's behaviour varies over time (consistency is low), and that the person's behaviour differs in different situations (differentiation is high), external attributions will be made. In other words the person's behaviour will be ascribed to external factors from the environment. Should it, however, be observed that the person's behaviour differs from that of other persons (consensus is low), that the person's behaviour remains the same over time (consistency is high), and that the person's behaviour is the same in different situations (differentiation is low), internal attributions will be made. In other words, the person's behaviour will be attributed to internal factors which relate to the individual (Greenberg \& Baron, 2000:58; Robbins \& Judge, 2007:148-149; Boshoff, 2009:65-67). 


\section{Differences between individuals with an internal locus of control and individuals with an external locus of control}

According to Robbins et al. (2003:123) and Hume et al. (2006:50, 56 ), individuals with an external locus of control are less likely to accept responsibility for the consequences of their behaviour. Furthermore, such individuals are more inclined to rely upon external influences in the course of making decisions and in general behaviour. According to Robbins (2001:96) individuals with external locus of control experience less job satisfaction, higher absenteeism, and are less involved in their occupational duties. Edwards (2005: 578) states that external-locus individuals are less self-directed and tend to drift along in life, often feeling frustrated, and prone to blaming others for mishaps. External-locus individuals also tend to experience more stress than internal-locus individuals (Norton, 2005: 634).

Individuals in possession of an internal locus of control, however, rely upon internal standards to differentiate between right and wrong (Robbins et al., 2003:123; Hume et al., 2006:50-51). Individuals with an internal locus of control associate the outcomes of the organisation with their own actions. Such individuals take personal responsibility for unfavourable conditions in the organisation (Robbins et al., 2003:123; Hume et al., 2006:50-51). Jones and George (2003:79) add that individuals with an internal locus of control attempt to intervene in order to change a situation or solve a problem, and are thus directly involved in problem-solving. Furthermore, individuals with an internal locus of control have good coping skills and tend to resist peer pressure to conform. Individuals with an internal locus of control also tend to experience less stress and respond to difficulties in a positive way (Norton, 2005:578, 634).

Contradictory findings are reported regarding the relationship between locus of control and the individual's religious beliefs. Various authors, such as Spilka et al. (1985:8) and Flugel (Rasmussen \& Charman, 1995:109-110) indicate that there is a positive relationship between external locus of control and the individual's degree of religiosity, as said individuals obtain direction and guidance from God (which they regard as an "instrument" or "external" form of control). Other authors, such as Wong-McDonald and Gorsuch (2004:321) distinguish a further dimension, namely God control, which encompasses both internal and external locus of control. It follows that God is viewed as the external Creator of everything, but 
also the internal Presence which is established in each who believe. In contrast, Jackson and Coursey (1988:399) found a positive relationship between internal locus of control and God control. Should focus be placed on the definition of the construct internal locus of control, as well as the characteristics associated with individuals who possess an internal locus of control, the authors concur with the findings of Jackson and Coursey (1988:399).

Though God may be viewed as an external influence, the choice to be influenced by Him fundamentally makes for internal control. God gives man the choice (internal control) of whether or not to invest belief in Him and the choice (internal control) of whether or not to act according to his guidelines. This compliments the positive relationship found in this study between internal locus of control and ethical behaviour, as well as the findings of Kennedy and Lawton (1998: 163), who found that individuals who are more inclined towards religiousness are less inclined towards unethical behaviour.

Apart from the above-mentioned differences between individuals with an internal and external locus of control, Hume et al. (2006:56) indicate that locus of control has a significant influence on ethical behaviour. According to Stead et al. (1994:59) individual characteristics, such as locus of control, shape ethics and decisions. Chonko et al. (1996:44) add that individual decision-making characteristics such as locus of control could provide insight on ethical reasoning. Trevino and Youngblood (1990:378-379) and Trevino et al. (2006: $965)$ indicate that the connection between behaviour and the consequences thereof are more likely to be noted by individuals with an internal locus of control. As a result, responsibility is more readily assumed by such individuals.

\section{Methodology}

\subsection{Formulation of the research hypothesis}

The following hypotheses were investigated in this study:

- Null hypothesis (HO): There is no statistically significant relationship between scores achieved on locus of control and scores achieved on ethical behaviour among employees in the financial sector in the Free State.

- Theoretical hypothesis (H1): There is a statistically significant relationship between scores achieved on locus of control and 
scores achieved on ethical behaviour among employees in the financial sector in the Free State.

\subsection{Sample selection}

Employees from the financial sector in the Free State (with specific reference to the banking industry) were involved in the study. Only a certain banking industry (who wished to remain anonymous) was prepared to participate in the study. It was necessary to rely upon the willingness of the employees to participate in the study, as employees could not be compelled to participate. According to the Human Resources Department of the specific banking industry they consist of 800 employees. Sekaran (2000:295) states in this regard that in order for a sample to be representative of a population of 800 employees, 260 employees should be included in the sample. However, only 100 employees were prepared to be included in the sample. Therefore, non-probability sampling, and specifically convenience sampling, were used. Questionnaires were completed anonymously. With regard to the composition of the sample, the majority of respondents (76\%) fell in the age category of 20 to 40 years; $61 \%$ of the respondents were female; $62 \%$ were white; and the majority of respondents (75\%) were Afrikaans speaking. Furthermore, the majority of respondents $(51 \%)$ were in possession of at least a Grade 12 with between 1 to 3 years tertiary education. Although only 100 respondents could be included in this study, the results (see par. 6.2) - on grounds of Guilford's guide to interpret statistically significant relationships - can still be interpreted as a definite (although small) relationship (Tredoux \& Durrheim, 2002).

\subsection{Data gathering methods}

The Work Beliefs Questionnaire and Schepers' Locus of Control Questionnaire were used in order to measure respondents' ethical behaviour and locus of control.

\subsubsection{Schepers' Locus of Control Questionnaire}

Schepers' Locus of Control Questionnaire is conceptually based on the social learning theory and attribution theory. Sixty-five items were composed and subjected to both factor analysis and secondorder factor analysis. The factor analysis of the items yielded the following three factors, namely internal control, external control, and autonomy (Schepers, 1995:12). 
The Locus of Control Questionnaire has been extended to include 80 items (each measured on a 7-point scale) in order to increase the reliability of the various scales. Schepers' Locus of Control Questionnaire is standardised for South African conditions and the reliability of the questionnaire can be regarded as satisfactory (Schepers, 1995:2, 24).

\subsubsection{The Work Beliefs Questionnaire}

The Work Beliefs Questionnaire was developed by Abratt, Nel and Higgs (1992:30). This questionnaire consists of 28 ethical situations to which respondents must respond in terms of the 5-point Likert approach. A total ethical score is given. The Work Beliefs Questionnaire is standardised for South African conditions and has face validity.

\subsection{Statistical methods}

Statistical methods which were employed in this study include both descriptive and inferential statistics. With regards to inferential statistics, the relationship between locus of control and ethical behaviour were ascertained by means of Pearson's product-moment correlation coefficient.

\section{Results and discussion}

\subsection{Averages and standard deviations of ethical behaviour and locus of control}

Following is an exposition of the averages and standard deviations of ethical behaviour as well as the dimensions of locus of control.

Table 1: The averages and standard deviations of ethical behaviour and the dimensions of locus of control

\begin{tabular}{|c|c|c|}
\hline & Average & Standard deviation \\
\hline Level of ethical behaviour & 47.44 & 15.379 \\
\hline \multicolumn{2}{|c|}{ Locus of control dimensions } \\
\hline Internal locus of control & 141.98 & 21.566 \\
\hline External locus of control & 87.73 & 17.485 \\
\hline Autonomy & 133.06 & 20.289 \\
\hline
\end{tabular}

It must be noted that the scales of the Work Beliefs Questionnaire 
(WBQ) are such that a high score indicates a low level of ethical behaviour, while a low score indicates a high level of ethical behaviour. Therefore, from Table 1 it is evident that a low total score (high level of ethical behaviour) is present among respondents represented in the sample. Respondents also scored high on internal locus of control and autonomy and low on external locus of control.

\subsection{The relationship between dimensions of locus of control and ethical behaviour}

Table 2 provides an exposition of the relationship between the various dimensions of locus of control and ethical behaviour.

Table 2: The relationship between locus of control and ethical behaviour $\left({ }^{*} p \leq 0,05\right)$

\begin{tabular}{|c|c|c|}
\hline Dimension & r-value & Significance (p) \\
\hline Internal locus of control & -0.208 & $0.038^{\star}$ \\
\hline External locus of control & 0.238 & $0.017^{\star}$ \\
\hline Autonomy & -0.238 & $0.017^{\star}$ \\
\hline
\end{tabular}

From Table 2 it is evident that there is a statistically significant $(p \leq 0,05)$ relationship between respondent's levels of ethical behaviour and the following dimensions of locus of control:

\section{- Ethical behaviour and internal locus of control}

The results indicate a statistically significant inverse relationship $(p \leq 0,05)$ between internal locus of control and levels of ethical behaviour. This indicates that individuals who achieve a high score on internal locus of control achieve low scores on levels of ethical behaviour. Bearing in mind that low scores indicate a high level of ethical behaviour, individuals who achieve a high score on internal locus of control therefore have greater levels of ethical behaviour.

\section{- Ethical behaviour and external locus of control}

The results indicate a statistically significant relationship $(p \leq 0,05)$ between external locus of control and levels of ethical behaviour. This indicates that individuals who achieve a high score on external locus of control achieve high scores on levels of ethical behaviour. As high scores indicate a low level of ethical behaviour, individuals who achieve a high score on external locus of control therefore have lower levels of ethical behaviour. 


\section{- Ethical behaviour and autonomy}

The results indicate a statistically significant inverse relationship $(p \leq 0,05)$ between autonomy and levels of ethical behaviour. This indicates that individuals who achieve a high score on autonomy, achieve low scores on levels of ethical behaviour. Bearing in mind that low scores indicate a high level of ethical behaviour, individuals who achieve a high score on autonomy therefore have greater levels of ethical behaviour.

The aforementioned results are supported by the findings of previous research studies (see par. 4).

On the basis of the above-mentioned data the null hypothesis is consequently rejected and the theoretical hypothesis accepted. This means that there is a statistically significant relationship between locus of control and ethical behaviour among employees in the financial sector in Bloemfontein.

\section{Conclusions and recommendations}

Although the above-mentioned results are supported by previous research (see par. 4), this article provides a demonstration of the way in which locus of control may influence ethical behaviour among employees working in the financial sector. Based on the results and discussion of results, it is clear that employees in the financial sector with a prominent internal locus of control, have greater levels of ethical behaviour. Employees in the financial sector with a high score on autonomy also have greater levels of ethical behaviour. In contrast, employees with a prominent external locus of control (and low levels of autonomy), have lower levels of ethical behaviour (meaning poor ethical behaviour).

The results of the study can be utilised in further development of strategies and interventions to minimise unethical behaviour in the financial sector, as well as in organisations in general. The following can be done:

- Implement programs that focus on the development of an internal locus of control among employees. Employees must be taught to take responsibility for their actions and must be rewarded should such behaviour be exhibited. Research (Boshoff, 2001:43-48) indicated that the following personality attributes are related to internal locus of control:

- being independent; 
- being controlled and self-disciplined;

- being self-sufficient, prefers own decisions and being resourceful;

- being conscientious and persevering.

The development of the above-mentioned personality factors can be focused on with regard to programs with the view to development of an internal locus of control.

- Ethics training courses must be presented within the organisational context. Focus must be placed specifically on the ethical approaches available during decision-making. The advantages and disadvantages of each approach must also be highlighted. It is important that individuals are aware of their dominant decisionmaking approach. The Work Convictions Questionnaire (Boshoff, 2009:278-281), which provides a measure of the philosophical approaches regarding ethical decision-making, can be used for this purpose. Further research regarding the relationship between individual characteristics (such as locus of control) and an individual's prominent ethical decision-making approach is also needed.

- Given the important role which religion plays in the establishment of the individual's value system and the regulation of behaviour, it is also vital that religion be incorporated within ethics courses. Religious institutions can play a pivotal role by allowing representatives to act as guest speakers. Here, emphasis must be placed specifically on the establishment of certain universal values within the organisational context (e.g. respect for all, incorruptibility, integrity, fairness, honesty) which apply to all individuals in any given circumstance.

- In the light of the role that locus of control plays in an individual's level of ethical behaviour, it is also important that organisations take these factors into account during the selection of employees.

\section{Limitations and opportunities for future research}

Future research can focus on the effect of biographical variables on the relationship between locus of control and ethical behaviour. By focusing on the effect of inter alia gender, age, managerial level and home language on the relationship between locus of control and ethical behaviour, more accurate recommendations can be made. 
To fully understand the complexity of the findings of the current study it is suggested that a more representative sample be obtained. Furthermore, it is also suggested that in order to get a more detailed description of the relationship between locus of control and ethical behaviour, as well as to improve understanding of this complex relationship, future studies can employ more than one variable together with suitable statistical techniques to model this relationship (for instance multiple-regression analyses and structural-equation modelling).

\section{List of references}

ABRATT, R., NEL, D. \& HIGGS, N.S. 1992. An examination of the ethical beliefs of managers using selected scenarios in a cross-cultural environment. Journal of business ethics, 11(1):29-35.

ANON. 2007. SA, capital of white-collar crime. Mail \& Guardian (online) 16 Oct. http://mg.co.za/article/2007-10-16-sa-capital-of-whitecollar-crime.html Date of access: 16 Oct. 2010.

BOSHOFF, E. 2001. Die verband tussen persoonlikheidseienskappe en werkstres by onder-offisiere in die Suid-Afrikaanse Nasionale Weermag. Bloemfontein: Universiteit van die Vrystaat. (M.A.-verhandeling.)

BOSHOFF, E. 2009. Die ontwikkeling van 'n werksetiekvraelys gebaseer op 'n holistiese filosofiese model van etiese besluitneming. Bloemfontein: Universiteit van die Vrystaat. (Ph.D.-tesis.)

BOTHMA, A.C. \& SCHEPERS, J.M. 1997. The role of locus of control and achievement motivation in the work performance of black managers. Journal of industrial psychology, 23(3):44-52.

CHONKO, L., TANNER, J. \& WEEKS, W. 1996. Ethics in salesperson decision making: a synthesis of research approaches and an extension of the scenario method. Journal of personal selling \& sales management, 16(1):35-52.

DE KOKER, L. 2007. Financial crime in South Africa. Economic affairs, 27(1):34-38.

DU TOIT, E., MAITLAND, C., MAKINA, D., MAREE, A. \& PILBEAM, E. 2007. XKit undergraduate financial management. http://www.books.google.com Date of access: 23 Aug. 2010.

DUSKA, R.F. 2005. A look at integrity in financial services. Journal of financial services professionals, 59(5):26-28.

EDWARDS, D.J.A. 2005. Personality. (In Louw, D.A. \& Edwards, D.J.A., eds. Psychology: an introduction for students in Southern Africa. Sandton: Heinemann. p. 541-604.)

FALCONER, S. 2005. Ethical marketing in financial services: the continuing importance of fiduciary responsibility. Journal of financial services marketing, 10(2):103-106.

FREEMAN, R.E. 1991. Business ethics: the state of the art. New York: Oxford University Press.

GERDES, L.C., OCHSE, R., STANDER, C. \& VAN EDE, D. 1988. Die ontwikkelende volwassene. Durban: Butterworth. 
GLOEK, J.D. \& DE JAGER, H. 2005. Fraud profiles of public sector institutions in South Africa. Southern African journal of accountability and auditing research, 6:49-65.

GREENBERG, J. \& BARON, R.A. 2000. Behaviour in organizations: understanding and managing the human side of work. London: Prentice Hall.

GROBLER, P., WARNICH, S., CARRELL, M.R., ELBERT, N.F. \& HATFIELD, R.D. 2006. Human resource management in South Africa. London: Thompson Learning.

HEIDER, F. 1958. The psychology of interpersonal relations. New York: Wiley.

HELLRIEGEL, D., SLOCUM, J.W. \& WOODMAN, R.W. 2010. Organizational behaviour. Mason: South-Western Cengage Learning.

HUME, E.C., SMITH, A. \& STEPHEN, F. 2006. University student ethics: the differential explanatory effect of locus of control. Academy of educational leadership journal, 10(3). http://www.alliedacademies.org/Publications/Papers/AELJ\%20Vol\% 2010\%20No\%203\%202006.pdf\#page=55 Date of access: 23 Aug. 2010.

JACKSON, L.E. \& COURSEY, R.D. 1988. The relation of God control and internal locus of control to intrinsic religious motivation, coping and purpose in life. Journal for the scientific study of religion, 27(3):399-410.

JONES, G.R. \& GEORGE, J.M. 2003. Contemporary management. New York: McGraw-Hill.

KENNEDY, E.J. \& LAWTON, L. 1998. Religiousness and business ethics. Journal of business ethics, 17:163-175.

KOHLBERG, L. 1969. Stage and sequence: the cognitive-developmental approach to socialization. (In Goslin, D.A., ed. Handbook of socialization theory and research. Chicago: Rand McNally College Publishing Company. p. 347-480.)

KREITNER, R. \& KINICKI, A. 2007. Organizational behaviour. New York: McGraw-Hill.

MALAN, F. \& SMIT, B. 2001. Ethics and leadership in business and politics. Lansdowne: Juta.

MARTIN, J. 2005. Organizational behaviour and management. London: Thomson Learning.

MCSHANE, S.L. \& VON GLINOW, M.A. 2000. Organizational behaviour. New York: McGraw-Hill.

NASH, L.L. 1994. Why business ethics now? (In Drummond, J. \& Bain, B., eds. Managing business ethics. London: Heinemann. p. 7-25.)

NEUBECK, K.J. \& GLASBERG, D.S. 1996. Sociology: a critical approach. New York: McGraw-Hill.

NORTON, G. 2005. Stress and coping. (In Louw, D.A. \& Edwards, D.J.A., eds. Psychology: an introduction for students in Southern Africa. Sandton: Heinemann. p. 605-663.)

O'DONNEL, M. \& GARROD, J. 1990. Sociology in practice: an introduction to sociology and social science. Walton-on-Thames: Nelson.

PARSONS, P.J. 2007. Ethics in public relations: a guide to best practice. London: Kogan Page.

PRICEWATERHOUSECOOPERS. 2007. The 4th biennial global economic crime survey: economic crime, people, culture \& controls. Pricewaterhousecoopers. 
RABL, T. \& KÜHLMANN, T.M. 2008. Understanding corruption in organizations: development and empirical assessment of an action model. Journal of business ethics, 82:477-495.

RASMUSSEN, L. \& CHARMAN, T. 1995. Personality and religious beliefs: a test of Flugel's superego projection theory. The international journal for the psychology of religion, 5(2):109-117.

ROBBINS, S.P. 2001. Organizational behaviour. Upper Saddle River: Prentice Hall.

ROBBINS, S.P. \& JUDGE, T.A. 2007. Organizational behaviour. Upper Saddle River: Pearson Education.

ROBBINS, S.P., ODENDAAL, A. \& ROODT, G. 2003. Organisational behaviour: global and Southern African perspectives. Cape Town: Pearson Education.

ROTTER, J.B. 1966. Generalized expectations for internal versus external control of reinforcement. Psychology monographs: general and applied, 80(1):1-28.

SAFAKLI, O.V. 2005. A research on the ethical dimension of banking crises in the Turkish Republic of Northern Cyprus (TRNC). Electronic journal of business ethics and organization studies, 10(2). http://www.ejbo.jyu. fi/archives/vol10_no2.html Date of access: 19 Aug. 2010.

SCHEPERS, J.M. 1995. Die lokus van beheer-vraelys: konstruksie en evaluering van 'n nuwe meetinstrument. Johannesburg: Departement van Menslike Hulpbronbestuur, Randse Afrikaanse Universiteit.

SCHEPERS, J.M. 2005. The construction of a normative scale of locus of control. SA journal of industrial psychology, 31(3):1-11.

SEKARAN, U. 2000. Research methods for business: a skill-building approach. New York: Wiley.

SPECTOR, P.E. 2008. Industrial \& organisational psychology: research and practice. New York: Wiley.

SPILKA, B., SHAVER, P. \& KIRKPATRICK, L.A. 1985. A general attribution theory for the psychology of religion. Journal for the scientific study of religion, 24(1):1-20.

SQUIRE, D. 2007. Corporate governance and ethical behaviour. http://www.ruff.co.za/print/5390_CORPORATE_GOVERNANCE_AND_ ETHICAL_BEHAVIOUR.htm Däte of access: 23 Aug. 2010.

STEAD, W., WORRELL, D.L. \& STEAD, J.G. 1994. An integrative model for understanding and managing ethical behaviour in business organizations. (In Drummond, J. \& Bain, B., eds. Managing business ethics. London: Heinemann. p. 58-73.)

TREDOUX, C. \& DURRHEIM, K. 2002. Numbers hypotheses and conclusions: a course in statistics for the social sciences. Cape Town: University of Cape Town Press.

TREVINO, L.K. \& NELSON, K.A. 2007. Managing business ethics: straight talk about how to do it right. New York: Wiley.

TREVINO, L.K., WEAVER, G.R. \& REYNOLDS, S.J. 2006. Behavioural ethics in organizations: a review. Journal of management, 32(6):951-990.

TREVINO, L.K. \& YOUNGBLOOD, S.A. 1990. Bad apples in bad barrels: a causal analysis of ethical decision-making behaviour. Journal of applied psychology, 75(4):378-385.

WEISS, J.W. 1998. Business ethics: a stakeholder and issues management approach. Fort Worth: Dryden Press. 
WONG-MCDONALD, A. \& GORSUCH, R.L. 2004. A multivariate theory of God concept, religious motivation, locus of control, coping, and spiritual wellbeing. Journal of psychology and theology, 32(4):318-334.

\section{Key concepts:}

business ethics

ethical behaviour

financial sector

locus of control

unethical behaviour

\section{Kernbegrippe:}

besigheidsetiek

etiese gedrag

finansiële sektor

lokus van beheer

onetiese gedrag 
